DOI: 10.17707/AgricultForest.62.4.14

\author{
Danguolè JUŠKEVIČIENE், Rasa KARKLELIENE், \\ Audrius RADZEVIČIUS, Audrius SASNAUSKAS ${ }^{1}$
}

\title{
PRODUCTIVITY AND MORPHOLOGICAL FEATURES OF GARLIC (ALLIUM SATIVUM L.) GROWN IN LITHUANIA
}

\section{SUMMARY}

Garlic (Allium sativum L.) is the second most popular vegetable in the genus Allium in Lithuania. The field collection of garlic in the LRCAF Institute of Horticulture was established in 1992. New accessions enter the collection continually.

The aim of the research was to determine the productivity and structure of yield, to assess the morpho-biological features of 24 hardneck and the 14 of softneck garlic clonal accessions. Colour of external scale of bulbs, number of cloves in a bulb, arrangement and skin colour were estimated according guidelines for DUS test. The data of yield was statistically processed by the ANOVA method and analysis of principle coordinates within SPSS.

Results showed the differences in productivity and morphological features between both of types, populations and cultivars. The yield of hardneck garlic bulbs reached $16.8 \mathrm{t} \cdot \mathrm{ha}^{-1}$, and lower yield $12.1 \mathrm{t} \cdot \mathrm{ha}^{-1}$ was found of softneck garlic. Local populations of hardneck garlic showed higher possibility of yield formation compared with the foreign cultivars. More cloves per bulb were observed from softneck garlic accessions, while hardneck garlic distinguished with the formation of heavier cloves.

Three garlic cultivars Žiemiai, Dangiai and Vasariai are included in the National List of Plant varieties and Common catalogue EU of vegetable species varieties.

Keywords: garlic bulb, morphobiological variation, yield, cultivar

\section{INTRODUCTION}

Garlic (Allium sativum L.) is an important vegetable in Lithuania which takes one of the main positions beside onions, carrots, cabbages, red beets. Growing area of garlic takes about 500 ha according presented reports of Association of vegetable growers and personal contacts. Lithuanian Institute of Agrarian Economics informs that local growers do not provide garlic demand in Lithuania. Therefore garlic should be grown on a larger scale.

Two types of cultivar representing softneck and hardneck garlic different

\footnotetext{
1 Danguolè Juškevičienè, (corresponding author: d.juskeviciene@1sdi.lt), Rasa Karklelienè, Audrius Radzevičius, Audrius Sasnauskas , Institute of Horticulture, Lithuanian Research Centre of Agricultural and Forestry Science, Kaunas distr., LITHUANIA.

Paper presented at the $7^{\text {th }}$ International Scientific Agricultural Symposium "AGROSYM 2016".

Notes: The authors declare that they have no conflicts of interest. Authorship Form signed online.
} 
according their productivity and morphological features are cultivated in Lithuania. The softneck (not forming flower stalk) garlic is planted early in spring (March-April) and hardneck (forming flower stalk) garlic in autumn (October) traditionally. Planting of garlic in spring was more popular growing method in the past, while planting of cloves in autumn is becoming more popular at present. Local populations and cultivars are mainly grown, but many of new foreign cultivars are available from seed companies and retailers. Using of planting material from nonlocal sources can be result of an unpredictable yield of bulbs. Bulb size, shape, colour of scales, number of cloves can be not display the characteristics that are presented in the catalogs. This is a result of large variability of bulb size, colour of scale, yield, and flavour influenced by genetic factor, climatic conditions, growth environment and production year (Grégrova, 2013, Moravčević et al., 2011, Volk and Stern, 2009, Waterer and Schmitz, 1994).

Many reports concerning with morphological features of various garlic cultivars are presented (Al-Zahim et al., 1997, Castellanos et al. 2004, Engeland, 1995, Ipek, 2003, Maa $\beta$ and Klass, 1995, Waterer and Schmitz, 1994). Identification of uniform and stable traits can afford a ground for indication of typical morphotypes of garlic cultivars in different climatic conditions and growth regions.

Lithuanian cultivars are positively assessed by experts and consumers. But regarding of assortment increasing of imported cultivars it is hard to choose one suitable to the growing demands for obtaining high quality yield and the profitability of production.

The aim of this investigation was to assess and to compare differences among garlic morphotypes, national and foreign populations and cultivars according their productivity, to evaluate morphobiological features. Results of the investigation give a possibility to determine of important qualitative parameters of garlic populations and cultivars and to optimize of garlic growing strategy. Cloves of the best samples will be used for the creation of new cultivars as breeding material.

\section{MATERIAL AND METHODS}

Investigation was carried out in crop rotation of the experimental field at the Institute of Horticulture Lithuanian Research Centre for Agriculture and Forestry (IH-LRCAF) in 2013 - 2015. Soil type: sandy light loamy Calc(ar)iEpihypogleyicLuvisol (LVg-p-w-cc) (Buivydaitè et al., 2001).

Total amount of investigated cultivars and populations reached 38 from which 24 samples representing hardneck morphotype and 14 softneck. Garlic representing of hardneck morphotype involved 8 cultivars of different origin: Žiemiai (Lithuania), J. Gribovo (Russia), Ducat and Unicat (Czech Republic), Liubasha (Ukraine), Teodor (Germany), Chinese (China), Spring Violeta (Spain) and 16 local populations: No.4, No.5, No.6, No.7, No.11, No.15, No.16, No.24, No.27, No.28, No.30, No.36, No.37, No.39, No.40, No.41. Samples representing 
of softneck garlic involved 2 cultivars: Vasariai (Lithuania) and Jarus (Poland) and 12 local populations: No.8-2, No.9, No.14, No.15, No.19-1, No.19-2, No.22, No.25, No.26, No.27, No.28, No.40.

Cloves of hardneck garlic with an average $7 \mathrm{~g}$ of weight were planted on the last decade of October (in 2013 and 2014) and respectively softneck garlic with an average weight $2 \mathrm{~g}$ on the first decade of April (in 2014 and 2015). Planting of cloves was carried out by hand in $1 \mathrm{~m}$ wide furrows. Distances of $25 \mathrm{~cm}$ between lines and $7 \mathrm{~cm}$ between plants were left. Area of record plot was $0.7 \mathrm{~m}^{2}$. Experiment was carried out in three replications. During growing season fertilization, weeding, chemical plant protection and top removing were carried out typically according to the standard recommendations. Harvesting of hardneck garlic bulbs was carried out on the second decade of July, when the lower leaves of 30- 50\% had dried. Sofneck garlic was harvested on the first decade in 2014 and on the second decade in 2015 of August when leaves had dried $80 \%$ and fall down. Bulbs were dried by using of active ventilation about two weeks. After drying bulbs were grated into two size fractions and total yield of garlic and its structure was determined.

Marketable yield was consisted of well developed, good quality bulbs with diameter above $4.0 \mathrm{~cm}$ of hardneck garlic and above $3.0 \mathrm{~cm}$ of softneck garlic. The rest bulbs were characterized as non-marketable, that includes small with diameter below $4.0 \mathrm{~cm}$ and $3.0 \mathrm{~cm}$ and damaged by diseases and pests. Ten marketable bulbs and ten cloves were weighted for the determination an average weight of a bulb and clove. Morphobiological features of 5 representative bulbs of each population and cultivar were estimated according guidelines for distinctness, uniformity and stability (DUS) test.

Such characterististics were included: colour of external scale of bulbs, number of cloves in a bulb, arrangement and skin colour.

The data of yield was statistically processed by the ANOVA method according to Fisher's and Duncan's multiple range for mean separation at 5\% significance level and analysis of principle coordinates within SPSS (Statistical Package for the Social Sciences, 2002) SoftwareV.II.5.

Meteorological conditions: Good system of roots is one of the most important factors influencing productivity of garlic. The mean temperature was 5.4 and $4.9^{\circ} \mathrm{C}$ in October of 2013 and 2014, respectively the amount of precipitation reached 45.2 and $48.8 \mathrm{~mm}$. In November the temperature reached 2.6 and $3.8^{\circ} \mathrm{C}$ and amount of precipitation was 45.8 and $43.3 \mathrm{~mm}$. Meteorological conditions were favourable for rooting of hardneck garlic. The mean temperature in April of 2014 and 2015 had not exceeded $8.1^{\circ} \mathrm{C}$ therefore conditions were optimal for softneck garlic rooting. Air temperature in May, June and July of both year investigations was similar, but amount of precipitation was more than twice higher in 2014 than at the same period in 2015. This influenced better formation and growing of bulb in 2014. June was dry in 2015, but there were raining often in July, therefore was not missing of drought for softneck garlic growing. 


\section{RESULTS AND DISCUSSION}

Lithuanian consumers prefer hardneck garlic bulbs with high dry weight and white colour or other light coloured of external scale. Desirable diameter of bulb it is about $4 \mathrm{~cm}$ and above.

The total yield of the investigated hardneck garlic populations and cultivars varied from 4.5 to 16.8 th ha-1 in 2013-2015 (Table 1). Population No.30 distinguished with the significantly highest productivity.

The total yield of national cultivar Žiemiai reached $12.9 \mathrm{t} \cdot \mathrm{ha}-1$. According results of three years investigations it was determined that marketable yield of all populations and cultivars constitutes an average $87 \%$ in the total yield.

The significantly highest marketable yield 15,8 t.ha-1 was obtained from population No.30. It was determined 11 samples that formed the significantly heaviest bulbs. The average weight of a bulb of these samples reached from 72 to 82 g. Cloves number of hardneck garlic reached from 7.1 to 11.1 per bulb. Obtained results proved that number of cloves per bulb is affected by genetically factors. According Mahadeen A.Y. (2011) and Reghin et al.(2004) small ( $<1 \mathrm{~g})$ seed cloves produced the least number of cloves, while Ahmed et al. (2007) disagreed with this position.

Colour of external scale of bulb is an important morphological parameter describing their economic value, because it is determined by the requirements of consumers. In the investigation bulbs and cloves was observed of variegated colour, sometimes with the anthocyanin stripes on dry external scales. Colour of external scales of local populations and foreign cultivars was constant, while some researchers present high variability among cultivars across different growth locations (Waterer and Schmitz, 1994, Volk and Stern 2009).

Investigated samples showed their hardneck phenotype and formed flower stalk from the central part of bulb, except cultivar Teodor that did not produce the flower stalk. Cloves of all samples showed single arrangement in a bulb.

The total yield of softneck garlic varied from 4.5 to $12.1 \mathrm{t} \cdot$ ha-1 (Table 1). Population No.40 formed the significantly highest total, marketable yield and amount of cloves per bulb.

Marketable yield reached $11.2 \mathrm{t} \cdot \mathrm{ha}-1$, respectively the number of cloves 24.8. Statistically significant differences of cloves number among other populations were not determined, except a few samples. Populations No.9, No.14, No.15, No.28 and No.40 formed the heaviest bulbs respectively from 21 to $26 \mathrm{~g}$.

All investigated samples of softneck garlic did not form the flower stalks and cloves were arranged into two-three layers in a bulb.

External colour of dry scale was white or cream and colour of cloves skin varied among tested cultivars and populations from light purple to white or white with the anthocyanin stripes. 
Table 1. Garlic productivity and morphological features 2013-2015

\begin{tabular}{|c|c|c|c|c|c|c|c|}
\hline $\begin{array}{l}\text { Cultivar/ } \\
\text { Population }\end{array}$ & $\begin{array}{c}\text { Total } \\
\text { yield } \\
\left(\mathrm{t} \cdot \mathrm{ha}^{-1}\right)\end{array}$ & $\begin{array}{c}\text { Marketable } \\
\text { yield } \\
\left(\mathrm{t} \cdot \mathrm{ha}^{-1}\right)\end{array}$ & $\begin{array}{l}\text { Average } \\
\text { weight of } \\
\text { marketable } \\
\text { bulb } \\
\text { (g) }\end{array}$ & $\begin{array}{c}\text { Colour of } \\
\text { bulb external } \\
\text { scales }\end{array}$ & $\begin{array}{c}\text { Number } \\
\text { of } \\
\text { cloves }\end{array}$ & $\begin{array}{l}\text { Colour of } \\
\text { cloves skin }\end{array}$ & $\begin{array}{l}\text { Arrangement } \\
\text { of cloves }\end{array}$ \\
\hline \multicolumn{8}{|c|}{ Hardneck garlic } \\
\hline Žiemiai & 12,9 & 11,9 & $55 \mathrm{~cd}$ & White & $11,1 \mathrm{a}$ & White cream & Single \\
\hline No.24 & 14,4 & 13,9 & $82 a$ & White+stripe & $7,1 \mathrm{~cd}$ & Cream purple & Single \\
\hline Gribovo & 8,5 & 7,4 & $70 \mathrm{~b}$ & Purple & $8,2 \mathrm{c}$ & \begin{tabular}{|l|} 
Purple \\
\end{tabular} & Single \\
\hline Ducat & 7,2 & 6,0 & $44 \mathrm{e}$ & Cream & $7,3 \mathrm{~cd}$ & White & Single \\
\hline Unicat & 9,4 & 8,0 & $41 \mathrm{e}$ & purple & $8,3 \mathrm{c}$ & White purple & Single \\
\hline Liubasha & 12,8 & 12,1 & $69 \mathrm{ab}$ & Purple & $9,4 \mathrm{~b}$ & Light purple & Single \\
\hline Teodor & 7,8 & 5,8 & $80 \mathrm{a}$ & White & $10,4 a$ & White crem & Single \\
\hline Chinese & 4,5 & 3,8 & $27 \mathrm{~d}$ & White & $7,4 \mathrm{~cd}$ & White & Single \\
\hline Spring & 7,5 & 6,2 & $41 \mathrm{e}$ & Pruple & $8,3 c$ & Prple & Single \\
\hline Violeta & & & & & & & Single \\
\hline No.4 & 9,6 & 9,2 & $78 \mathrm{a}$ & White & $7,2 \mathrm{~cd}$ & Crem & Single \\
\hline No.5 & 8,7 & 6,9 & $75 b$ & Light purpule & $8,0 \mathrm{c}$ & Purple+stripe & Single \\
\hline No.6 & 14,3 & 17,1 & $71 \mathrm{~b}$ & White & $8,7 \mathrm{e}$ & White & Single \\
\hline No.7 & 11,6 & 10.8 & $71 \mathrm{~b}$ & White+stripei & $7,1 \mathrm{ed}$ & Lght purple & Single \\
\hline No.11 & 9,1 & 7,8 & $80 a$ & \begin{tabular}{|l|} 
White \\
\end{tabular} & 7,1 ed & & Single \\
\hline No.15 & 10,9 & 9,7 & $76 \mathrm{ab}$ & White & $9,4 \mathrm{~b}$ & White & Single \\
\hline No.16 & 14,4 & 13,1 & $76 \mathrm{ab}$ & Crem & $7,8 \mathrm{c}$ & Creme & Single \\
\hline No.27 & 6,8 & 5,3 & $39 \mathrm{e}$ & White+stripe & $7,8 \mathrm{c}$ & Light purple & Single \\
\hline No.28 & 7,4 & 6,0 & $43 \mathrm{e}$ & White & $8,2 \mathrm{c}$ & White & Single \\
\hline No.30 & 16,8 & 15,8 & $78 \mathrm{a}$ & Crem & $9,8 \mathrm{ab}$ & White cream & Single \\
\hline No.36 & 7,8 & 6,1 & $39 \mathrm{e}$ & Light Purple & $9,1 \mathrm{~b}$ & White+stripe & Single \\
\hline No.37 & 10,3 & 8,9 & $72 b$ & White+stripe & $10,6 \mathrm{a}$ & Light purple & Single \\
\hline No.39 & 10,9 & 10.0 & $62 c$ & White+stripe & $7,6 \mathrm{~cd}$ & Purple & Single \\
\hline No.40 & 13,9 & 12,5 & $81 \mathrm{a}$ & White & $11,0 \mathrm{a}$ & Cream & Single \\
\hline No.41 & 12,8 & 11,8 & $62 \mathrm{c}$ & Dark purple & $8,8 \mathrm{c}$ & Dark purple & Single \\
\hline $\mathrm{LSD}_{05}$ & 2,3 & 2,0 & & & & & \\
\hline \multicolumn{8}{|c|}{ Softneck garlic } \\
\hline No.8-2 & 5,8 & 5,4 & $19 \mathrm{~b}$ & White & $19,6 \mathrm{~b}$ & White & 2 layers \\
\hline No.9 & 4,4 & 3,9 & $21 \mathrm{ab}$ & White+stripe & $14,8 \mathrm{c}$ & Light purple & 3 layers \\
\hline No.14 & 9,4 & 8,9 & $21 \mathrm{ab}$ & White & $14,1 \mathrm{c}$ & Cream & 2-3 layers \\
\hline No.15 & 7,2 & 6,0 & $21 \mathrm{ab}$ & White & $15,1 \mathrm{c}$ & White cream & 2 -3layers \\
\hline No.19-1 & 9,4 & 9,0 & $16 \mathrm{~b}$ & Cream & $14,9 \mathrm{c}$ & Cream & 2 layers \\
\hline No.19-2 & 8,9 & 8,7 & $17 \mathrm{~b}$ & Cream & $14,6 \mathrm{c}$ & Cream & 2 layers \\
\hline No.22 & 5,4 & 4,4 & $14 \mathrm{bc}$ & White & $16,1 \mathrm{bc}$ & White & 2 layers \\
\hline No. 25 & 6,2 & 5,0 & $16 \mathrm{~b}$ & Cream & $13,1 \mathrm{c}$ & White & 2-3 layers \\
\hline No.26 & 5,5 & 4,1 & $14 \mathrm{bc}$ & White & $12,6 \mathrm{e}$ & White+purple & 2-3 layers \\
\hline No.27 & 6,7 & 5,6 & $18 \mathrm{~b}$ & Crem & 13,3 ed & Cream & 2-3 layers \\
\hline No. 28 & 5,8 & 5,0 & $22 a$ & White & $13,4 \mathrm{ed}$ & White+purple & 2 layers \\
\hline No.40 & 12,1 & 11,2 & $26 \mathrm{a}$ & White & $24,8 \mathrm{a}$ & White & 2-3 layers \\
\hline Jaris & 9,8 & 9,0 & $18 \mathrm{~b}$ & White & $15,0 \mathrm{e}$ & White cream & 2 layers \\
\hline Vasariai & 9,9 & 8,9 & $17 \mathrm{~b}$ & White & $14,6 \mathrm{c}$ & Cream & 2 layers \\
\hline $\mathrm{LSD}_{05}$ & 1,4 & 1,2 & & & & & \\
\hline
\end{tabular}

Means followed by the same letter within the column do not differ significantly at $\mathrm{P}=0.05$ (Duncan's multiple range test). 
The principal coordinate analysis (PCA) showed different ability of all investigated populations and cultivars for the productivity. According obtained results it is clear that it is possible to classify the investigated samples of hardneck garlic into several groups with different potential possibilities for yield and bulb formation (Fig. 1A). Garlic cultivar Žiemiai, populations No.39 and No.40 were located into one group on the PC1 scatter plot with high positive value and their yield reached from 10.9 to $12.9 \mathrm{t} \cdot \mathrm{ha}^{-1}$ and weight of bulb from 55 to $62 \mathrm{~g}$. Cultivar Teodor and nine local populations were located in one big group at the PC scatter plot. Samples on this group distinguished with ability for the heaviest bulb formation and averaged weight of bulb reached $75-82 \mathrm{~g}$. Cultivars from Spain, Czech Republic, China and three local populations were located in another group on the front side of the scatter plot. The yield and weight of a bulb of these samples were obtained the lowest and varied respectively from 4.5 to 9.4 $\mathrm{t} \cdot \mathrm{ha}^{-1}$ and from $27-44 \mathrm{~g}$.

These results confirm the conclusions of other authors that garlic is very sensitive to the climatic conditions and its growth environment (Volk and Stern, 2009, Engeland, 1991, Waterer and Schmitz, 1994).

PCA of softneck garlic yield and bulb weight confirms a wide location of investigated populations and cultivars. Populations No.14 and No.40 were located separately from other samples at the PC scatter plot with high positive value (Fig.1B). These populations distinguished with the highest yield formation, respectively 9.4 and $12.1 \mathrm{t} \cdot \mathrm{ha}^{-1}$.

\section{Principal Coordinates}

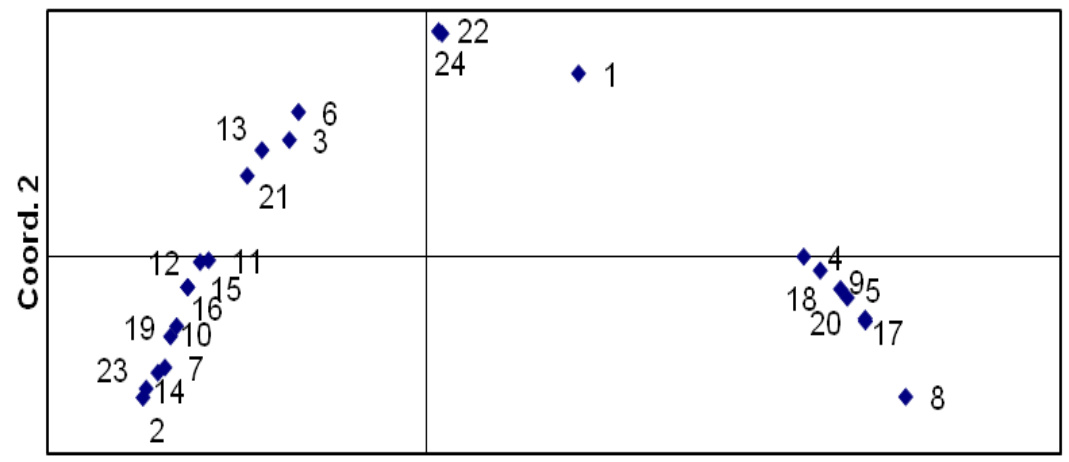

Coord. 1

1 - Žiemiai; 2 - No.24; 3 - J.Gribovo; 4 - Ducat; 5 - Unicat; 6 - Liubasha; 7 - Teodor; 8 - Chinese; 9 - Spring Violeta; 10 - No.14; 11 - No.5; 12 - No.6; 13 - No.7; 14 - No.11; 15 - No.15; 16 No.16; 17 - No.27; 18 - No.28; 19 - No.30; 20 - No.36; 21 - No.37; 22 - No.39; 23 - No.40; 24 No.41.

Fig.1 A. Scatter plot of various hardneck garlic populations and cultivars according to the results of principled coordinate analysis (PC) of total yield and weight of bulb data in 2013-2015 


\section{Principal Coordinates}

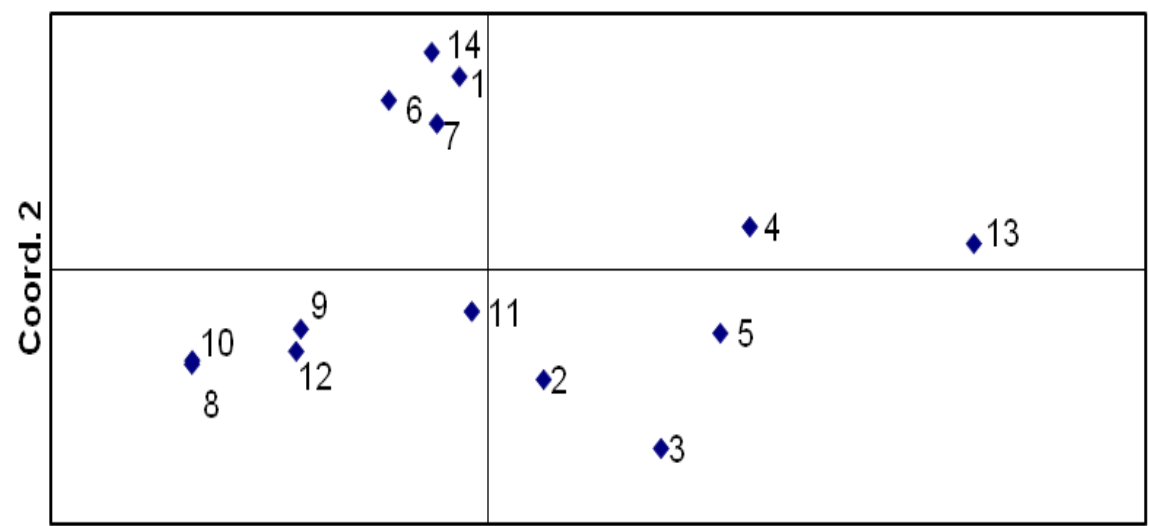

Coord. 1

1 - Vasariai; 2 - No.2; 3- No.9; 4 - No.14; 5 - No.15; 6 - No.19-1; 7 - No.19-2; 8 - No.22; 9 No.25; 10 - No.26; 11 - No.27; 12 - No.28; 13 - No.40; 14 - Jarus.

Fig.1B. Scatter plot of various softneck (B) garlic populations and cultivars according to the results of principled coordinate analysis (PC) of total yield and weight of bulb data in 2013-2015

The results obtained in our investigation and reports of other researchers prove that cultivar is an important factor that affects plant productivity (Karklelienè et al. 2015, Volk and Stern, 2009, Waterer and Schmitz, 1994).

Comparison of different cultivars and hybrids creates a presumption for practical purpose to choose the most valuable breeding product.

\section{CONCLUSIONS}

Investigated populations and cultivars of garlic were differed according their productivity and morphological features. Bulbs of local and foreign samples retained their hardneck or softneck morphotype. The yield of hardneck garlic bulbs reached $16.8 \mathrm{t} \cdot \mathrm{ha}^{-1}$, and lower yield $12.1 \mathrm{t} \cdot \mathrm{ha}^{-1}$ was observed of softneck garlic. Local populations of hardneck garlic showed higher possibility of yield formation. More cloves per bulb were obtained from samples of softneck garlic, while hardneck garlic distinguished with the formation of heavier cloves.

\section{ACKNOWLEDGEMENTS}

This work was carried out within the framework of the long-term research program "Genetics and direct genotype development of agricultural and forestry plants" implemented by Lithuanian Research Centre for Agriculture and Forestry. 


\section{REFERENCES}

Ahmed H.G., Magaji M.D., Yakutu a.I., Singh A. (2007). Responce of garlic (Allium sativum L.) irrigation interval and clove size in semi-arid. Nigeria J. of Plant Science 2 (2): 202-208.

Al Zahim M., Newbury H.J., Ford-Lloyd B.V. (1997). Classification of genetic variation in garlic (Allium sativum L.) revealed by RAPD. HortSciencia 32: 1102-1104.

Buivydaitė V., Vaičys M., Juodis J., Motuzas A. (2001). Lietuvos dirvožemių klasifikacija. Vilnius.

Castellanos I.Z., Vargas -Tapia P., Ojodeagua J.L., Hoyos G. (2004). Garlic Productivity and Profitability as affected by Seed Clove Size, Planting Density and Planting Method. HortScience 39(6): 1272-1277.

Engeland R.L. (1995). Growing great garlic (suppl.) Filaree Productions, Okanogan, WA. Grégrova A., Čížková H., Bulantová I., Rajchl A., Voldřich M. (2013). Characteristics of Garlic of the Czech Origin. Chech J. Food of Sci., Vol. 31, No 6: 581-588.

Ipek M.A. Ipek, Simon P.W. (2003) Comparison of AFLPs, RAPD markers, and isozymes for diversity assessment of garlic and detection of putative duplicates in germplasm collections. J. Amer. Soc. Hort. Sci.128: 246-252.

Karklelienė R., Dambrauskienė E., Juškevičienė D., Radzevičius A., Rubinskienè M., Viškelis P. (2014). Productivity and nutritional value of dill and parsley: Horticultural Sciences (Prague), 41(3): 131-137.

Maa $\beta$ H.J., Klass M.(1995). Intraspecific differentiation on garlic (Allium sativum L.) by isozyme and RAPD markers: Theor. Appl. Genet. 91: 89-97.

Mahadeen Atif Y. (2011). Influence of Clove Weight on Vegetative Growth and Yield of Garlic (Allium sativum L.) Grown under Drip Irrigation. Jordan Journal of Agricultural Sciences, Vol. 7, No 1, pp. $44-49$.

Moravčević Đ, Bjelić V., Moravčević M., Gvozdanović Varga J., Beatović D., Jelačić (2011). The effect of plant density on bulb quality and yield of spring garlic (Allium sativum). Proceedings 46thCroatian and 6th International Symposium on Agriculture. Opatija. Croatia: 554 - 557.

Reghin M.Y., Otto R. F., Zagonel J., Pria M.D., Van Der Vinne J. (2004). Yield resonce of garlic to different plant densities and weights of seed cloves. Cientia Agrotechnologia 28 (1): 87-94.

SPSS Inc. (2002). SPSS for windows release 11.5. Chicago.

Volk G. M., Stern D. (2009) Phenotypic Characteristics of Ten Garlic Cultivars Grown at Different North American Locations. HortScience 44(5):1238-1247.

Waterer D., Schmitz D. (1994). Influence of variety and cultural practices on garlic yields in Saskatchewan. Can. J. Plant Sci. 74: 611-614. 